\title{
AS ÁGUAS QUE MARGEIAM A HISTÓRIA E A ESTÓRIA: UMA ANÁLISE SOBRE O PÓS-COLONIAL E A INFÂNIA NA OBRA A CHUVA PASMADA DE MIA COUTO
}

\author{
Júlia Zuza \\ Universidade de Coimbra)
}

\section{RESUMO}

O artigo propõe a discussão de conceitos como nação e identidade na obra A chuva pasmada do autor moçambicano Mia Couto, destinada para o público infanto-juvenil. A perspectiva do narrador-criança no livro descortina uma gama de sentidos nas relações entre infância, identidade e pós-colonialidade e, juntamente com as metáforas criadas a partir do elemento água, criam na narrativa fronteiras fluidas entre a história e a estória.

PALAVRAS-CHAVE: Mia Couto, infância, pós-colonialidade.

\begin{abstract}
The paper presents a discussion of concepts such as nation and identity in the work A chuva pasmada by Mozambican author Mia Couto, aimed to children and juvenile public. The perspective of the child narrator in the book reveals a range of meanings in the relationship between childhood identity and postcoloniality, and together with the metaphors created from the water element, create the narrative fluid boundaries between history and story.
\end{abstract}

KEYWORDS: Mia Couto, childhood, postcoloniality. 
A obra A chuva pasmada do moçambicano Mia Couto apresenta um vasto mosaico de linguagem e múltiplos sentidos e, através do olhar da infância, discute temas como pobreza, racismo, oralidade, pós-colonialidade e seus desdobramentos. $\mathrm{O}$ autor possui outros livros destinados à infância e adolescência - Mar me quer (2000), O gato e o escuro (2001) e O beijo da palavrinha (2008). Para além dos textos voltados para o público citado, a temática da infância é recorrente em sua criação literária, como se nota nos protagonistas infantis de Terra Sonâmbula (1995) e Jesusalém (2010). Faz-se relevante perceber quais os mecanismos textuais utilizados para debater questões mais densas em um texto destinado para o público infanto-juvenil e que possui uma criança como personagem principal.

O livro conta sobre a chuva que ficou presa entre céu e terra em uma pequena vila e retrata como a família do narrador-criança lida com a circunstância. Não se sabe ao certo se o protagonista relata o acontecido muito ou pouco tempo depois, como se pode notar na primeira frase do livro: "Nesse dia, meu pai apareceu em casa todo molhado. Estaria chovendo?" (COUTO, 2004, p. 6). O uso de "nesse dia" seria proposital, pois cria-se no leitor a dúvida se aquela era uma conversa que já estava sendo estabelecida e foi retomada ou se havia sido iniciada naquele momento, numa estratégia de não delimitar historicamente o fato. Isso permitiria que o acontecimento pudesse ter se dado há uma semana ou há vinte anos. A maioria dos verbos no livro está empregada no pretérito, tanto perfeito como imperfeito, reforçando que são lembranças do narrador e potencializando o universo mágico da trama. A utilização de dois tempos verbais (era, apareceu, estaria, guardava), aumenta a indeterminação temporal da história, uma vez que o pretérito perfeito é quase sempre utilizado para indicar uma ação já realizada, como em "apareceu”. Nesse caso, o leitor pode entender que de fato aquela ação ocorreu, que de fato algo ou alguém apareceu. Já a utilização do pretérito imperfeito e futuro do pretérito gera uma dubiedade, trazendo para a narrativa um grau de indeterminação, vista em "era" e "estaria", respectivamente. O tempo verbal conferiria um tom mais mágico, recurso possivelmente empregado pelo autor para designar a atmosfera imaginativa narrada. Para a atual análise, é pertinente perceber como se delineia a perspectiva dos fatos pela visão infantil.

Como o próprio título do livro indica, a água merece relevo no texto. O elemento realiza na história um pano de fundo para a discussão de questões profundas, como o papel desempenhado pela tradição. Outro ponto que o livro toca pela via da chuva/água/rio são os problemas sociais e econômicos daquele povoado, pois a fábrica gerenciada pelos brancos apenas gera pobreza na comunidade.

No livro de Mia Couto, quando o rio seca e faz com que parem as máquinas da fábrica que produziam a fumaça, a chuva finalmente cai: "O rio se extinguira, a fábrica desmaiara, os fumos desvaneciam. De súbito, deflagraram ventanias e cacimbos, gotas e poeiras, tudo se juntou num redemoinho imenso e subiu nos céus, em girações e vertigens, até se forma- 
rem nuvens espessas e cinzentas" (COUTO, 2004, p. 71). É também com a morte do rio que a normalidade volta a ser estabelecida na comunidade de Sembora. O embate da água com a fábrica merece atenção especial. A chuva que não cai pode representar o poder colonial sobre Moçambique, que inverte a lógica, trazendo desgraça e pobreza. Apesar de o rio estar extinto, a fábrica está apenas "desmaiada", o que poderia revelar que o poder exercido pela antiga metrópole permanece, onde a dominação política é substituída pela dominação econômica, que interfere em todos os campos, inclusive no ciclo da água que é rompido. Segundo Césaire (2011), por onde a colonização europeia esteve, a introdução da economia fundada no dinheiro gerou o enfraquecimento ou destruição dos laços tradicionais. O que o trecho de Mia Couto parece salientar é que, estando apenas "desmaiada", a fábrica poderá acordar e voltar a funcionar a qualquer momento, o que indicaria a necessidade daquela vila se preparar para assumir o controle da situação, evitando assim o retorno dos tempos em que a fábrica ditava as ordens. Sobre esse quadro de nova configuração do poder colonial e autonomia política e social, parece relevante citar:

O pós-colonial pressupõe, por conseguinte, uma nova visão da sociedade que reflecte sobre sua própria condição periférica, tanto a nível estrutural como conjuntural. [...] o que não quer dizer, a priori, tempo de independência real e de liberdade, como o prova a literatura que tem revelado e denunciado a internalização de outro no pós-independência. (MATA, 2007, p. 39)

Seria importante rever e repensar as consequências de anos de dominação colonial mesmo após a independência política dos países, pois há ecos do colonialismo em vários aspectos da sociedade moçambicana, como visto na exploração que a fábrica impunha à vila. $\mathrm{O}$ menino protagonista revela toda a miséria e opressão que sua família e comunidade sofriam com a fábrica: "até ali eu apenas podia calçar um sapato de vez. Assim, imparmente, poupava os calçados" (COUTO, 2004, p. 26). Pode ser estabelecido o paralelo com a situação econômica de Moçambique, uma vez que seria preciso lutar contra a situação vigente de descaso e injustiça. Era necessária uma mudança irrevogável para que os passos daquela nação, representada pelo par de sapatos desfalcado, voltassem a caminhar em direção ao futuro.

Mas, para haver a mudança, era preciso escapar da pasmaceira, palavra utilizada no título da obra. Quando se analisa a palavra "pasmada", percebe-se que estar pasmado é uma reação e não uma ação; é uma consequência. Só é possível ficar pasmado diante de algo, mediante uma situação ou pessoa. O resultado gerado é de espanto e surpresa, deixando muitas vezes em um estado de inexpressividade o pasmado ou pasmada. A chuva da história de Mia Couto está entre o céu e a terra em função da grande quantidade de fumaça liberada pela fábrica instalada na aldeia. A chuva e a população de Sembora ficaram "pasmadas", sem atitude frente aos abu- 
sos e injustiças cometidos pela fábrica: "Aquela chuva se imobilizava junto ao solo? Pois também, o meu pasmado pai, tinha estancado junto à vida" (COUTO, 2004, p. 69). A passagem revela que a criança estava ciente da situação política e social de sua família, pois é feita uma crítica ao pai do narrador e ao resto da vila, que estavam apáticos diante daquela realidade. A renúncia da água em não atingir o solo pode ser lida como uma medida extrema para que as pessoas se mobilizassem e reagissem. $\mathrm{O}$ pai do protagonista é chamado de pasmado, mas no decorrer da história se percebe que sua falta de iniciativa era na verdade fruto dos anos de exploração que sofreu nas minas de carvão onde trabalhou:

Olhei o seu rosto cansado como se encontrasse nele razões para sua atitude, sempre ausente e preguiçosa. Ainda miúdo, meu pai tinha ido para as minas, lá no Johni. Saíra jovem, voltara envelhecido. [...] Anos depois meu pai regressou mas permaneceu ausente, como se lhe faltasse algum inferno. E partiu de novo. E regressou. E voltou a partir. De cada vez que voltava, vinha mais e mais doente. (COUTO, 2004, p. 14)

A criança protagonista desempenha na história o papel de observadora atenta, ao mesmo tempo em que é vítima daquela situação de subalternidade junto com sua família. A pasmaceira em que se encontra o pai se reflete em sua feição, envelhecida precocemente. A doença de que padece é a doença de não ter mais esperança, de estar desacreditado no futuro e em melhoras. $O$ trabalho que exercia dentro das minas é também rico em leituras, pois no subterrâneo não se pode ver a luz, a claridade. Interessante notar que, quando o pai sai da mina e vem à tona, deseja regressar para debaixo da terra, como alguém que já está morto simbolicamente, podendo significar que a superfície era tão ou mais escura e sem perspectiva como as minas. A indiferença do pai e da família representaria, segundo Spivak (2010), uma das formas por que o imperialismo, entendido como uma das consequências do pós-colonialismo, tentaria silenciar o subalterno, de forma a paralisá-lo em sua diferença. O inferno de que o pai sente falta, segundo o narrador, poderia ser encontrado também fora do subterrâneo, visto que os moradores de Sembora são oprimidos.

A subalternidade e a dominação podem também ser lidas nos trechos em que a mãe do protagonista resolve ir à fábrica para resolver a situação dos fumos e passa a ter encontros frequentes e a sós com o patrão branco:

Passou uma mão a ajeitar o lenço, acertou a roda da saia na cintura e, autoritária, me arrastou pelo braço, como se apressasse um peso morto.

- Diga-me mãe, aquele senhor escutou as nossas razões?

Ela nada respondeu. Apenas suas unhas se espetaram na minha carne. Estranhei o afiado daquela dor. (COUTO, 2004, p. 29)

O excerto revela o jogo de poder a que estavam submetidos os moradores. A mulher tenta fazer de seu corpo uma moeda de troca para 
que o dono da fábrica atendesse suas solicitações, o que revelaria também uma subalternidade de gênero. As unhas que ela crava no braço do filho podem transmitir a humilhação a que se viu sujeita a aceitar, em prol do bem de toda sua família. A dor que a mãe transmite para o pequeno protagonista reafirma tanto sua condição de colonizada como a condição de colonizador do homem branco, o que, para Memmi (1977), é a legitimidade necessária para que a opressão colonial permaneça.

O desenrolar dos encontros termina com a revelação da mãe ao filho: “- Verdade, mãe? Esse homem branco não abusou da senhora? Desde o primeiro dia, ele me desejou, sim. Mas o homem não era capaz. Disse-me que eu cheirava à minha raça" (COUTO, 2004, p. 62). Mais uma humilhação fica evidente no trecho, pois, apesar da atração física que sentia pela mulher, o homem não conseguia aceitar que ela fosse negra. A problemática do racismo aparece na violência da frase "cheirava à minha raça", denunciando de que forma os moçambicanos eram vistos pela elite econômica branca da região. E vale a pena perceber que, quando o homem comenta sobre o cheiro da raça, não se dirige exclusivamente à mãe, mas sim a todos os negros, de forma indistinta: "O objecto do racismo é, não descriminar o homem particular, mas uma certa forma de existir" (FANON, 2011, p. 274). Mesmo que o narrador seja uma criança, já compreende a relação de desigualdade entre sua família e os poderosos, pois pergunta à mãe se o homem não havia abusado dela.

O menino protagonista também sofre diretamente com o preconceito racial. Uma das cenas mais emblemáticas da narrativa é a que revela a brincadeira entre a criança branca e a negra, evidenciando o racismo do menino branco ao ser convidado para jogar berlindes com o protagonista negro:

- Não quer jogar, menino?

- Não posso.

- Porquê?

- O meu pai não deixa. Não me deixa brincar com... com vocês.

Eu já sabia. Só não disse a palavra: pretos (COUTO, 2004, p. 28).

Apenas quando percebe que seu pai não está olhando para os dois através da janela da fábrica é que o menino branco se permite brincar. A cena demonstra o afastamento forçado entre as duas crianças e que consegue ser quebrado pela brincadeira: "O menino ainda hesitou. Mas, depois, o seu joelho ganhou a terra e iniciámos um jogo" (COUTO, 2004, p. 28). O menino branco obedece por alguns minutos às regras do jogo do pai, jogo estabelecido sob o pensamento colonial. Mas o menino negro consegue subverter essa condição e estabelece o contato entre eles, mesmo que por pouco tempo. As crianças burlam o sistema e se entregam à infância, brincando, ainda que por minutos, sem distinção de raça ou de cor. $\mathrm{O}$ jogo de berlindes retratado pode ser entendido como um breve contraponto no jogo do sistema colonialista, pois aquela brincadeira conseguiu, por instantes, quebrar algumas das grandes barreiras impostas à população negra. 
Porém, como se faz notar no desenrolar da narrativa, há uma mudança iminente naquela sociedade, muitas vezes relacionada com o ciclo da água: "Aos poucos, a água se vestiu de caudal. E se escutava já o remoinhar alegre da corrente. O rio refazia as suas margens" (COUTO, 2004, p. 73). O rio antigo que alimentava a fábrica é extinto e um rio novo, fruto da tão esperada chuva, começa a brotar do chão. As águas que nascem marcam o nascimento de um novo tempo para a vila, uma renovação, metaforizando o (re) nascimento da nação e a reflexão sobre a identidade moçambicana, sempre levando em consideração a infância do narrador e como ele se relaciona com os temas citados. A água assume papel primordial, uma vez que somente após a formação de nuvens e a liberação da chuva que estava presa, a mudança efetiva é sinalizada no texto e a família do protagonista se encaminha para o rio seco que está prestes a nascer: um novo Moçambique estava a apontar, liberto das injustiças advindas da dominação econômica estrangeira. No livro, o rio que finda representa a derrota do poder colonial, seja ele político ou econômico, porém deixando marcas.

Nesse contexto, os moçambicanos comemoram o iniciar de uma nova era, entusiasmados em reafirmar e repensar sobre a nação que refaz suas margens, como cita o livro. Sob esse ponto de vista, os rios novos são a projeção do futuro e da esperança de paz e mais igualdade, como as águas que banham os sonhos de uma terra que acaba de ressurgir. Nesse aspecto, seguem as palavras de Macêdo (2002):

No caso dos textos de Luandino Vieira e Mia Couto, os rios não são apenas projeções do humano. Eles são construídos pelos homens, por sua vontade, assim como a nação e a paz são utopicamente construídas no sonho diurno, no cotidiano e no exercício do escrever, de contar histórias exemplares. É, pois, uma imensa tarefa que aí se propõe: edificar rios e seus (dis) cursos por onde possa, então, navegar. (MACÊDO, 2002, p. 104)

O ciclo desse elemento, contínuo, volta a ser estabelecido somente no final da narrativa, reforçando a ideia de Macêdo (2002). O rio e a água são importantes veículos entre gerações, sobretudo entre o neto e seu avô, pois este é o único familiar que possui laços afetuosos com o menino protagonista, conversando com ele e dando-lhe atenção: "Recordei os tempos em que, todos os domingos, ele me levava à pesca. Sem conversas, nos quedávamos na margem enquanto olhávamos o rio e suas eternidades" (COUTO, 2004, p. 35). A comunhão entre avô e neto acontece em silêncio, não sendo necessárias palavras para que se entendam e dividam um momento especial. Pescar, no contexto citado, se aproxima a um ritual, em que a observação é mais importante que a fala. Quando o neto analisa os gestos do avô na beira do rio todos os domingos, é possível pensar que estivesse sendo preparado pelo seu mais velho, numa relação que perpassaria pela transmissão de valores antigos, na tentativa de não deixar morrer os costumes e crenças daquele povo: "Eu que não emprestasse ouvido aos restantes, crédulos em espíritos e mezinhas. Que isso não era de civilizado. Sobretu- 
do, não desse crédito ao avô, ele era o mais dado aos ancestrais" (COUTO, 2004, p. 19). Na obra de Mia Couto, o prosseguimento da tradição na família parece ser possível somente entre os extremos da linha da vida: o neto-criança e o avô-ancião. Em outras obras do autor moçambicano, como em A varanda do frangipani (2007) e Um rio chamado tempo, uma casa chamada terra (2003), os idosos cumprem a função de transmitir às novas gerações o saber que precisa perdurar e permanecer. Para Alves (2012), o avô simboliza o passado e as tradições, ao passo que o neto representa o futuro, a esperança de um novo mundo. Sobre transmissão de saberes, Benjamin (1994) complementa a fala de Alves (2012):

A reminiscência funda a cadeia da tradição, que transmite os acontecimentos de geração em geração. Ela corresponde à musa épica em seu sentido mais amplo. Ela inclui todas as variedades da forma épica. [...]. Ela tece a rede que em última instância todas as histórias constituem entre si. Uma se articula na outra (BENJAMIN, 1994, p. 211-212).

O encargo do avô é manter acesa a chama da tradição, uma vez que narrar uma história é uma forma de resistir à morte dos costumes, além de transferir para o neto um saber ancestral: "Herdei do meu avô o sonho costumeiro de ir ter com o mar. Ser rio e fluir. Água em água, onda em onda, até escutar o grito agudo da gaivota" (COUTO, 2004, p. 56). Há vários termos que transportam o leitor para o universo da tradição, como as palavras "herdar", "sonho" e "fluir". No livro, o neto recebe do avô algo impalpável: o desejo de conhecer o mar. Faz-se entender que, para o avô, seu bem mais valioso e que merecia ser repassado era a vontade de ir além, pensamento que se interliga ao verbo "fluir". A ideia que esse verbo carrega é de movimento, de seguir caminho e não permanecer estático, assim como o saber contido na tradição deve seguir seu curso. Se a frase "ser rio e fluir", contida no excerto, for levada para o campo dos costumes e hábitos locais, poderá ser vista como uma cultura que está em constante movimento, transformada e modificada o tempo todo. O mesmo acontece com as histórias orais que ganham elementos diferentes quando são repassadas de geração em geração, fluindo no tempo e ganhando novos contornos. $\mathrm{O}$ excerto também revela que os ensinamentos do avô se perpetuaram e de alguma forma se faziam presentes na vida do neto, pois, como afirma Moreira (2005), o discurso da tradição apresenta uma vertente didática, dando valor e verdade a um costume ou uma crença.

Relacionada diretamente à questão do renascimento e da regeneração, estão a água e o tempo: "não era ao rio que iríamos agradecer. Era ao fio do tempo, esse costureiro da água que entrelaçava pingo da chuva com a gota do rio" (COUTO, 2004, p. 72). O rio, em A chuva pasmada, metaforiza a passagem do tempo, a continuidade. O ciclo da água, iniciado na gota da chuva (neto) e finalizando no rio (avô), pode ganhar a leitura do ciclo da vida, que se renova e se refaz. O tempo e o rio se fundem em um só corpo, como a sugerir a costura que o tempo faz com as várias fases da 
água e das gerações. O texto é banhado pela tradição, o que poderia indicar que o tempo ancestral é constantemente revisitado e se encontra entrelaçado na escrita, diluindo as fronteiras entre o antigo e o novo. Um excerto em especial ratifica a ideia do rio como elemento da tradição: "Assim se cumpre, sem mesmo eu saber, a intenção do meu velho avô: ele queria o rio sobrando da terra, vogando em nosso peito, trazendo diante de nós as nossas vidas antes de nós" (COUTO, 2004, p. 74). A fala do protagonista indica um caráter profético naquele novo rio criado, pois tudo já estaria predestinado a acontecer. O destino e a força da tradição ganham um peso maior nas sociedades mais antigas, pois, como afirma Moreira (2005), a crença ou costume confere ao discurso uma verdade da tradição ancestral, enfatizando o tom didático que esses saberes possuem. As vidas passadas que voltam em forma de ensinamento para o menino e seus parentes simbolizariam a memória, que, para Macêdo e Maquêa (2007), se apresenta como um campo móvel de significações, interpretação e experiência social. Poderia se dizer que o ressurgimento do rio é relacionado com o retorno às tradições, de forma a não deixá-las desaparecer. O avô desejava ver o rio dentro do peito de sua família, o que poderia dizer que o mais velho desejava que as tradições da família e sua memória não fossem perdidas e voltassem a ser importantes na vida dos personagens, de modo que eles carregassem de maneira afetuosa os valores do passado. A criança assume a função de dar continuidade aos saberes tradicionais, alimentando a chama da ancestralidade em sua família. Aquele rio seria o elo entre o passado e o futuro, pai e filho, morte e vida, em limites que não são estabelecidos de forma impositiva, criados de maneira orgânica e natural, assim como o curso das águas:

- Meu neto, me ajude a levar este barco até o rio.

[...] Recusei. Eu sabia o motivo desse pedido. Segurei o barco como se tivesse medo que, por força divina, ele resvalasse para o rio.

- Esse barco não sai daqui, avô!

- Mas qual é o seu medo? O rio não está seco? (COUTO, 2004, p. 66).

O rio pode ser lido como a ponte que liga a morte e a vida, garantindo a conexão entre os dois extremos. O barco será o instrumento utilizado pelo avô para seguir sua viagem no curso do tempo, ao entender que está na hora de deixar sua família. O neto sabe a finalidade do passeio e por isso se entristece, ciente que aquela partida seria realmente sem volta.

A capacidade simbólica da água na obra é ampliada quando o pai do menino resolve ajudá-lo a levar a canoa com o mais velho para o rio: "Os braços fortes dele se aplicaram no ventre da canoa. Ainda levei um tempo a ajustar-me ao espanto. [...]. - Por que me ajudou a levar a canoa? - Eu não o ajudei a si, filho. Eu ajudei-me a mim" (COUTO, 2004, p. 68). O rio foi o elemento responsável por unir as três gerações da família e criar um momento de comunhão entre eles e de redenção para o pai. Vale ressaltar que 
a expressão "ventre da canoa" pode se referir ao formato abaulado do barco e também ao renascimento do pai, pois foi com a partida do avô que ele decidiu retomar sua vida e assumir o protagonismo da situação. Para Leite (1998), as viagens nas obras de Mia Couto possibilitam a pacificação das origens, indicando a demanda de paz, de conciliação e confluência. O momento estaria fértil de ressignificações, pois o pai comenta que, ao ajudar o filho, ajudou a si próprio, reestabelecendo a relação entre os dois. Assim se reforça nesse sentido a regeneração da água, entendida por Chevalier e Gheerbrant (2005) como capaz de fazer renascer, apagando uma história antiga e estabelecendo um estado novo.

O renascimento do pai ocasiona o renascimento do menino protagonista. Após a viagem derradeira do avô que fortalece os elos entre pai e filho, a água inaugura uma nova fase para a criança: "Meu pai juntou as palmas das mãos, em concha, para colher aquele primeiro jorro de água. Essa água nua, acabada de nascer, ele a fez tombar sobre mim. Como se me estivesse dando um novo nome. Quando olhei em volta vi que a família inteira se havia ali ajuntado" (COUTO, 2004, p. 73). Há várias camadas simbólicas e cosmológicas no excerto. Ao pegar a água com as duas mãos e banhar o filho, acontece algo próximo a um ritual de batismo, em que o rio que acabara de nascer também provoca o nascimento daquela criança. A água nua e nascedoura representa, para Bachelard (2002), a purificação, em que ser mergulhado nas águas límpidas significa sair renovado e detentor de uma força fecunda e polivalente. O rio e o menino nascem juntos na história, numa analogia à nação que também se iniciava. As crianças também indicam um novo tempo nas narrativas e possuem "na literatura prometeica, como é a de toda a África, um papel muito importante, de gazuas do futuro, simbolizando, em última instância, o triunfo do novo sobre a velha tradição e sobre a dominação colonial" (LARANJEIRA, 1995, p. 128).

Merece destaque o papel que o protagonista infantil assume, pois é no batismo promovido pelo pai que toda a família se reúne em torno do gesto, mostrando pela primeira vez na história um momento partilhado por todos. A criança na história pode ser analisada como a metáfora do porvir, além de simbolizar o desejo de um novo tempo; a relação das crianças nas literaturas angolana e moçambicana, para Mata (2001), representa o amanhã/futuro e se harmoniza por outro lado com o passado, o tempo infantil, retrato do tempo primordial e genesíaco. Cabe às crianças, juntamente com as águas, representarem o advento de uma nova era, delineando um novo curso para a história e para o seguimento daquela nação.

Portanto, o olhar do menino protagonista no livro, muitas vezes imbricado com a função que a água desempenha na obra, não pode ser lido como um simples relato. A infância em A chuva pasmada é a metáfora de pontos substanciais da narrativa, reflexo de vários aspectos discutidos e rediscutidos em Moçambique atualmente, como o repensar de uma nação recente, os ecos da tradição naquela sociedade e os embates e relações com a modernidade, o peso do passado e do presente, a subalternidade e 
o racismo, dentre outros. Interessante perceber que o narrador-criança é ao mesmo tempo um observador da realidade que circunda sua família e um participante ativo, pois também é vítima direta das marcas do colonialismo, como o preconceito racial. Para além de seu sentido mais político, as águas e a infância, em A chuva pasmada transmitem uma alta carga de simbolismos, prioritariamente ligados a ritos de passagem e ressignificação de conceitos, como identidade e nação.

Por criar um vínculo ente diferentes tempos e linguagens através da alta capacidade conotativa das águas e a especificidade do olhar da criança, a obra de Mia Couto não define o que seria sonho e realidade, morte e vida, permitindo aos leitores que naveguem de maneira mais livre pela trama, criando margens porosas entre ficção e realidade, entre o vivido e o imaginado. Segundo Leite (1998), a mistura de vozes nas escritas do autor repõe a esperança de um outro tempo, em que a guerra e a miséria se transfiguram em elementos organizados por uma outra lógica, capaz de reestabelecer a harmonia e o equilíbrio. As fronteiras fluidas são muitas vezes construídas por meio da simbologia da água e seu campo lexical (chuva, rio, mar), em que o escritor consegue criar no texto literário o território onde modernidade, tradição, pós-colonialidade dialogam e se interpenetram, exibindo as várias camadas daquela cultura.

A infância pode ser lida no livro como a analogia do novo Moçambique que precisa questionar e interrogar sua história, ressignificando conceitos e ideias, pois "a ausência de um passado conhecido e reconhecido, a míngua de um passado, pode também ser fonte de grandes problemas de mentalidade ou identidades coletivas: é o caso das jovens nações, principalmente das africanas" (ASSORODOBRAJ apud LE GOFF, 2003, p. 208). A visão da criança-narradora revela as relações de poder estabelecidas dentro da pequena vila, espelho de todo um país que ainda reavalia as cicatrizes que permanecem vivas para a recente nação.

\section{REFERÊNCIAS BIBLIOGRÁFICAS:}

ALVES, Tatiana. Seis estudos sobre Mia Couto. Rio de Janeiro: Celacanto, 2012.

BACHELARD, Gaston. A água e os sonhos: ensaio sobre a imaginação da matéria. São Paulo: Martins Fontes, 2002.

BENJAMIN, Walter. O narrador. Considerações sobre a obra de Nikolai Leskov. In: Magia e técnica, arte e política: ensaios sobre literatura e história da cultura. São Paulo: Brasiliense, 1994, p. 197-221.

CÉSAIRE, Aimé. Cultura e colonização. In: Manuela Ribeiro Sanches (org). Malhas que os impérios tecem. Textos anticoloniais contextos pós-coloniais. Lisboa: Edições 70: 2011. p. 253-272. 
CHEVALIER, Jean; GHEERBRANT, Alain. Dicionário de símbolos. Rio de Janeiro: José Olympio, 2005.

COUTO, Mia. O beijo da palavrinha. Lisboa: Caminho, 2008. . A chuva pasmada. Lisboa: Caminho, 2004. . O gato e o escuro. Lisboa: Caminho, 2001. . Jesusalém. Lisboa: Caminho, 2010. . Mar me quer. Lisboa: Caminho, 2000. . Um rio chamado tempo, uma casa chamada terra. São Paulo: Companhia das Letras, 2003. . Terra sonâmbula. Rio de Janeiro: Nova Fronteira, 1995. . A varanda do frangipani. São Paulo: Companhia das Letras, 2007.

FANON, Frantz. Racismo e cultura. In: Manuela Ribeiro Sanches (Org). Malhas que os impérios tecem. Textos anticoloniais contextos pós-coloniais. Lisboa: Edições 70: 2011. p. 273-285.

LARANJEIRA, Pires. Literaturas Africanas de Expressão Portuguesa. Lisboa: Universidade Aberta, 1995.

LE GOFF, Jacques. História e memória. Campinas: Editora da Unicamp, 2003.

LEITE, Ana Mafalda. Oralidades \& escritas nas literaturas africanas. Lisboa: Edições Colibri, 1998.

MACÊDO, Tania. Angola e Brasil - estudos comparados. São Paulo: Arte \& Ciência, 2002.

MATA, Inocência. Literatura angolana: silêncios e falas de uma voz inquieta. Lisboa: Mar Além, 2001.

MEMMI, Albert. Retrato do colonizado precedido do retrato do colonizador. Rio de Janeiro: Paz e Terra, 1977.

MOREIRA, Terezinha Taborda. O vão da voz: a metamorfose do narrador na ficção moçambicana. Belo Horizonte: Editora PUC Minas, 2005.

SPIVAK, Gayatri Chakravorty. Pode o subalterno falar? Belo Horizonte: Editora UFMG, 2010. 